IZA DP No. 5912

Job Re-grading, Real Wages, and the Cycle

Robert A. Hart

J. Elizabeth Roberts

August 2011

Forschungsinstitut zur Zukunft der Arbeit Institute for the Study of Labor 


\title{
Job Re-grading, Real Wages, and the Cycle
}

\author{
Robert A. Hart \\ University of Stirling \\ and IZA
}

\author{
J. Elizabeth Roberts \\ University of Stirling
}

\section{Discussion Paper No. 5912 \\ August 2011}

\author{
IZA \\ P.O. Box 7240 \\ 53072 Bonn \\ Germany \\ Phone: +49-228-3894-0 \\ Fax: +49-228-3894-180 \\ E-mail: iza@iza.org
}

Any opinions expressed here are those of the author(s) and not those of IZA. Research published in this series may include views on policy, but the institute itself takes no institutional policy positions.

The Institute for the Study of Labor (IZA) in Bonn is a local and virtual international research center and a place of communication between science, politics and business. IZA is an independent nonprofit organization supported by Deutsche Post Foundation. The center is associated with the University of Bonn and offers a stimulating research environment through its international network, workshops and conferences, data service, project support, research visits and doctoral program. IZA engages in (i) original and internationally competitive research in all fields of labor economics, (ii) development of policy concepts, and (iii) dissemination of research results and concepts to the interested public.

IZA Discussion Papers often represent preliminary work and are circulated to encourage discussion. Citation of such a paper should account for its provisional character. A revised version may be available directly from the author. 
IZA Discussion Paper No. 5912

August 2011

\section{ABSTRACT}

\section{Job Re-grading, Real Wages, and the Cycle}

This paper makes use of the British New Earnings Survey Panel Dataset between 1976 and 2010. It consists of individual-level payroll data and comprises a random sample of $1 \%$ of the entire male and female labor force. About two-thirds of within- and between-company moves involve job re-grading (measured at 3-digit occupation level) while one-third of movers retain their job titles. We find that the real wages of both male and female workers who change job titles within companies are significantly more procyclical than job stayers. This lends support to the predicted procyclical real wage effects of the Reynolds-Reder-Hall job re-grading hypothesis. On the extensive margin, title changers and title retainers who move jobs between companies exhibit the same degrees of wage cyclicality and these are considerably greater than for job stayers.

JEL Classification: E32, J31

Keywords: $\quad$ real wage cyclicality, spot wages, job moves, job re-grading

Corresponding author:

Robert A. Hart

Division of Economics

University of Stirling

Stirling FK9 4LA

Scotland

United Kingdom

E-mail: r.a.hart@stir.ac.uk

\footnotetext{
* We are grateful to the Office for National Statistics (ONS) for granting access to the New Earnings Survey Panel Dataset (NESPD) and the Annual Survey of Hours and Earnings (ASHE). We also acknowledge ONS and the Scottish Government for enabling access to these data via the Virtual Micro-data Laboratory in Glasgow. Olaf Hübler kindly provided very useful comments on an earlier draft. We retain responsibility for errors.
} 


\section{Introduction}

In recent decades, micro empiricists have contributed greatly to macroeconomic debates concerning the observed high cyclicality of employment/unemployment in relation to the behavior of real wages. Wage rigidity had been viewed as the key driver in employment outcomes and up to the mid-1980s this seemed to be reasonably in line with empirical findings that leaned largely towards acyclical or weakly procyclical real wages. However, following the seminal paper of Bils (1985), micro longitudinal studies have found that North American and European real wages of within-company job stayers and between-company job movers are highly procyclical. Recently, Gertler and Trigari (2009) have argued that these findings do not preclude the prevalence of rigid wages among companies' new hires. Observations of withinand between-company wage procyclicality may arise because many job moves involve procyclical occupational re-grading with internal and external job movers placed on higher or lower pay scales compared to their previous employment. This does not preclude within-job wage rigidity post entry. To date, only one empirical micro study has directly addressed this issue. Using employer-based Portugese annual census data Martins, Solon, and Thomas (2010) are able to track the real wage patterns of cohorts of newly hired labor in over a thousand portof-entry jobs. They find resulting real wage procyclicality that is on a par with the general longitudinal stayer/mover micro evidence.

Nonetheless, the point raised by Gertler and Trigari (2009) about the need to identify the role of company job re-grading on real wages is generally important to the macreconomic study of real wage cyclicality. Not only are job moves that involve re-grading potentially 
instrumental in influencing real wage cyclicality between companies but also internal job moves may stimulate wage procyclicality within companies. Suppose that short run labor market frictions give rise to shortages and surpluses of certain skill categories of labor. Employers can react by changing job assignments among existing employees. They may undertake internal promotions of trainable labor to meet skill shortages while demotions and layoffs can be used to tackle employment surpluses. Procyclical internal wage changes would then reflect job moves entailing higher or lower pay scales. A combination of rigid intra-job wages combined with procyclical internal job re-grading are features of the main assumptions under the jobassignment hypothesis of Reynolds (1951), Reder (1955) and Hall (1974) (henceforth RRH). As also emphasised by Thurow (1975), what matters is the inherent marginal product of the job, not of the worker. A necessary condition is that eligible workers for a given internal promotion must be trainable to the level of achieving the new job's marginal product. In effect, 'workers compete with each other for openings for which scale wages are already established' (Hall, 1974).

This paper seeks to examine the roles played by job re-grading - as well as by job moves that involve no change in job title - on total national real wage cyclicality. Our data source is the British New Earnings Survey Panel Dataset (NESPD) between 1976 and 2010. It consists of a company-based $1 \%$ random sample of the entire male and female workforce. An essential quality of the NESPD for the investigation here is that the survey is jobs-based. We embrace several key questions. First, what are the relative cyclical effects on real wages of betweencompany job moves involving job re-grading? Jobs are defined at 3-digit occupational level. Recently, inter-company wage procyclicality has formed a major aspect of the search and 
matching framework of Pissarides (2009) that seeks to reconcile strong unemployment volatility with high wage flexibility in new matches. Second, what are the comparable real wage effects of within- company job moves? To date, United States support for internal wage procyclicality under the RRH hypothesis has not been strong and it is of interest to provide European evidence. A potentially important difference is that the role of one-sided implicit contracts has been regarded as playing a dominant influence on cyclical wage movements in the United States while in several European economies, including Britain, the spot wage market matters most. Third, what is the contribution of job re-grading, both internal and external, to total wage cyclicality? In particular, how does it compare with the aggregate effects of job stayers' wage movements? Fourth, what are the relative internal and external real wage effects of moves involving new job titles and those in which movers retain the titles of their previous jobs?

\section{Spot wages, implicit contracts, and job re-grading}

A large number of micro longitudinal studies in the United States and in several prominent European countries have established that wages of job stayers are strongly procyclical and that the real wages of inter-company job movers are even more procyclical. For a subset of the European economies, it has also been established that real wage changes associated with internal company job moves are more procyclical than the wages of job stayers. A useful summary is provided by Pissarides (2009, Tables II and III). These outcomes hold for Britain (see Devereux and Hart, 2006). They are consistent with the British finding of Devereux 
and Hart (2007), based on the methodology of Beaudry and DiNardo (1991), that spot market wage setting matters most. ${ }^{1}$ Kilponen and Santavirta (2010) have established similar support for spot wage setting in Finland.

In spot markets, we would expect real wages to rise and fall reasonably symmetrically with the ups and downs of the business cycle. What about between-company wage procyclicality in such a setting? Hagedorn and Masovskii (2009) define spot wages as depending on prevailing business conditions and on 'idiosyncratic productivities'. Job match quality and expected wages are positively associated with the number of per-period job offers a worker receives. During recessionary periods offers resulting from on-the-job search are relatively hard to come by in contrast to boom periods when search produces larger samples of offers from which to choose. Workers who are forced to leave companies during recessions, due to layoff and redundancy, may find it difficult to find alternative work that maintains previous wage levels. Workers who seek better job opportunities during booms will experience increased probabilities of improved match qualities and associated improved pay settlements.

If employers and workers are willing flexibly to adjust pay in relation to prevailing business conditions then this might well extend to another potentially important influence on

\footnotetext{
${ }^{1}$ Using the NESPD for the volatile business cycle period from 1976-2001 (see Figure 1), Devereux and Hart (2007) produce evidence based on simple wage sequencing and on regression analysis. They treat the annual real wage rate as constant if it changes by no more than $1 \%$ between successive years. Very few job spells contain constant real wages on this definition. Over $90 \%$ of job spells lasting 6 years or more contain both increases and decreases in real wages. Even within spells of 5 years or less, $47 \%$ (males) and $41 \%$ (females) exhibit real wage rises and falls. In their regressions of the full samples of males and females, the current unemployment rate produces the largest real hourly wage responses within job spells, although the minimum rate since the job start is also important. The regression coefficient on the contemporaneous unemployment rate is -0.01 for both men and women. This implies, in line with much European and North American evidence of real wage procyclicality, that a one-point increase in the unemployment rate reduces real wages by $1 \%$.
} 
the cyclicality of internal job movers' real wages. Raising real wage rates within a company during boom periods might fail to attract adequate numbers of job applicants given general short-term labor scarcity combined with increasing labor demand among competing companies. Skill shortages may especially feature. The RRH hypothesis in respect of the cyclicality of job assignments addresses this issue. Employers may attempt to meet labor shortages by lowering hiring standards, largely through internal promotions. Trainable workers would be up-graded from lower to higher skilled jobs that command higher pay scales. A decision to undertake such labor adjustments would depend on weighing up the payroll costs of general wage increases that are sufficiently high to fill job vacancies against those of lowering the quality of job matches due to job up-grading. ${ }^{2}$ During contractionary phases, excess labor supply allows employers to raise their hiring standards ${ }^{3}$ with workers down-graded from higher to lower paying job categories. In effect, down-graded workers would receive lower pay linked to the reduced marginal product resulting from the lower-level task requirements in their new jobs. Then procyclical up-grading and down-grading of job assignments produces procyclical wage effects among internal job movers.

${ }^{2}$ Job up-grading and down-grading involve several short-run costs to the employer. In the first place, job match quality is reduced through job movers being over- or under- qualified in their new job grades. As Solon, Whatley and Stevens (1997) point out, even if within-job wages were unchanged, job up-grading would mean that wages in terms of labor input per quality unit will rise. Second, up-grading will require additional training expenditures in order for internal movers to gain proficiency in the higher skill requirements of their new jobs. Third, layoff costs are incurred in respect of low skilled workers who are displaced by down-graded colleagues (see Devereux, 2002).

${ }^{3}$ See the discussion in Oi (1962). 
During a cyclical upturn in a spot wage market, all workers would expect to receive wage increases linked to strengthening business conditions. Additionally, up-graded workers would receive wage increments resulting from job promotions to higher occupational pay scales. In effect, the promotion would entail a promotion-linked wage increment and a cyclelinked wage increase received by all workers at each job level. Accordingly, the real wage procyclicality of internal job movers would be expected to exceed that of job stayers. Symmetric downward pressures on wages would apply during a downturn. Note that this is a somewhat different scenario from the maintained RRH hypothesis which suggests rigid withinjob real wages combined with procyclical wages of internal job movers. In fact, Solon, Whatley and Stevens (1997) find evidence for both cases. They test the hypothesis via case studies of the Ford and Byers companies in the US between the early 1920s and early 1930s. At Ford, there is little evidence of within-job wage cyclicality and this contrasts with findings of quite strong wage procyclicality resulting from internal changes in workers' job assignments. At Byers, both within-job wage movements and wage movements resulting from job reassignments are found to contribute significantly to overall wage procyclicality.

Beyond the Solon-Whatley-Stevens study, support for the RRH hypothesis has been lacking. Wilson (1997) analyses pay and other micro data from the records of two U.S. companies, one covering the period 1982-1994, the other 1969-1988. She finds no differences in the pay cyclicality of internal job movers compared with job stayers. Based on US data from the Panel Study of Income Dynamics (PSID) for 1981-1992, Devereux (2000) obtains wage outcomes that are broadly consistent with Wilson. One explanation of this more recent (lack of) evidence relates to the fact that North American research findings lean more towards a 
prominent role for insurance-type contracts in which employees are protected against fluctuations in labor income. Grout (1984) points out the greater importance of spot wages in the UK compared to the US where binding employer-union contracts are more prevalent. More importantly, the dominant finding is that one-sided implicit contracts that are non-binding on the employee are the principal type of contractual relationship. ${ }^{4}$ We might expect that this type of implicit contractual arrangement would be most prevalent among workers in higher skilled jobs since there would be incentives for employers to protect themselves against potential losses of firm-specific human capital investments (see Macleod and Malcomson, 1993 and Malcomson, 1999).

Devereux (2000) finds no evidence that within-company real wage procyclicality among job title changers is greater than among those reporting no changes in titles. He offers an explanation linked to the theory of firm-specific human capital. In normal times, workers with high specific skills share rents with employers. During recessionary periods, employers downgrade some of these workers as a form of labor hoarding. Layoffs take place among workers with low capital specificity. But job downgrading involves lower pay scales and employers run some risk of losing sunk investments due to job quits. An implicit contract may involve employers temporarily reducing their own rent shares in order to maintain the real wages of down-graded workers. They may calculate that the short-term costs associated with

\footnotetext{
${ }^{4}$ Support for the original Beaudry and DiNardo (1991) findings is provided by Grant (2003) for the US' and by McDonald and Worswick (1999) for Canada. Using the PSID between 1974 and 1991, Shin and Shin (2008) show that the pattern of procyclical real wages in the US for this period appears to be most consistent with an implicit contract explanation of wage formulation.
} 
sub-optimal job matches combined with downwardly rigid wages are outweighed by the longterm gains associated with the retention of skilled workers' labor services in respect of future periods of improved business conditions. In such a scenario, procyclical job re-grading does not necessarily imply procyclical real wages.

\section{Job moves and job titles}

The NESPD allows us to distinguish between two types of job moves that take place both within and between companies. First, moves that involve a change in job title as defined by a 3-digit occupation re-classification. Second, moves in which existing job titles are retained. The latter account for roughly one-third of male and female job moves in our data (see Table 1). This distinction carries potentially interesting wage cyclicality implications, especially in respect of differences between intra- and inter-company moves.

Job up-grading and down-grading under the RRH hypothesis is almost certainly dominated by internal moves that involve job title changes. Re-grading consists of workers who are promoted or demoted into higher or lower skill-level jobs. ${ }^{5}$ Internal moves under the same

\footnotetext{
${ }^{5}$ Many movements between pairs of 3-digit occupations are not easily identified by job title changes alone as representing up-grades or down-grades. But there are clear examples based on titles. In the unemployment cycle from 1982 to 1991 (see Figure 1), for example, our data records 24 cases of clerks up-graded to supervisors during periods of falling or constant unemployment and 16 cases in the opposite direction during rises in unemployment. Equivalently, there were 20 cases of promotion from sales person to marketing and sales managers and 8 cases in the opposite direction. But, inevitably, there are also cases of demotions occurring during improved market conditions and promotions during worsening conditions. Wage changes associated with job moves would be expected more accurately and comprehensively to signal changes in job task and skill requirements.
} 
job title represent a change in (at least some) job tasks but are unlikely to require significantly higher or lower skill inputs. In this event, increased wage procyclicality of internal movers due to changes in occupational pay scales is likely to be more apparent among title changers compared to title retainers.

What about between-company job moves? As the business climate picks up, job title changers, on average, would be expected to move to higher skilled jobs commanding higher pay scales. During a downturn, job scarcity may force redundant workers to down-grade into less skilled, lower paying jobs. But why would individuals move between companies, incurring associated moving costs, while retaining the same job description and title? While there are a number of possibilities that are not directly linked to wages ${ }^{6}$, such moves during a cyclical upturn are likely to appeal to high ability workers who do not wish to change their occupational job tasks but who seek to realize their 'true' marginal products by joining more productive companies. To a potential new employer, such moves offer strong job match quality and low transaction costs. Match quality is more assured if there are similarities or commonalities in task requirements between new and old jobs. Training expenditures are minimized. The risks associated with uncertainty over performance in respect of new task requirements are low. In a cyclical downturn, laid off workers may be forced to seek work under the same occupational job description in less productive, less well paying, companies. This would especially be the case among low skilled workers who offer prospective employers relatively narrow ranges of job capabilities.

${ }^{6}$ Examples include moves involving (a) a contemporaneous job move by a spouse or partner, (b) a desired change in residential location, (c) the attainment of a better work environment. 


\section{Data}

Our estimation consists of combining individual payroll data with national claimant count unemployment rates over the period 1976 to 2010 . Unemployment rates are shown in Figure $1 .^{7}$ The NESPD comprises a $1 \%$ random sample of the entire British workforce. All individuals are allocated a National Insurance (NI) number on reaching the minimum school leaving age and the NESPD sample is selected on the basis of a given pair of digits within the NI number sequence. Employers are legally required to fill in a short questionnaire on sampled individuals that relates to a specific week in April. The wages and hours data provided by employers are taken directly from company payrolls and are considered to be very accurate. Concentrating on full-time males and females, we use the standard hourly wage as our pay measure, defined as "gross weekly earnings divided by normal basic hours for employees whose pay for the period was not affected by absence." We deflate this measure using the Retail Prices Index. To avoid outliers, we excluded the top and bottom wage percentiles. Reestimation with hourly real earnings (including overtime pay and hours) produced no substantive differences to our results.

An important strength of the NESPD is that it is jobs based. Employers are asked to indicate whether the employee has remained in the current job for more than 12 months, thereby allowing us to distinguish between job stayers and job movers. Employers provide the

\footnotetext{
7 Each annual rate in Figure 1 is centered on the previous October. Wage agreements in Britain typically cover a 12-month period. The NESPD payroll data are collected in April of each year and so refer to settlements occurring between April and May of the previous year. October of the previous year is the 'representative' mid point.
} 
employee's full job title, including job rank or grade, as well as a short description of the work involved. On the basis of the collected information, jobs are classified by the Office for National Statistics into standard 3-digit occupation codes. ${ }^{8}$ The NI identifier allows individuals to be tracked from employer to employer and by geographical location through time.

For most of our study period, the NESPD does not allow us directly to separate job movers into intra- and inter- company movers. In order to make this separation, we adopt the procedure earlier carried out by Devereux and Hart (2006). We classify a between-company job mover as someone whose job move involves (a) a change in geographical location and/or (b) a change in 1-digit industrial classification ${ }^{9}$ and/or (c) a move between public and private sector employment. We have two variations of criterion (a): we use either moves across regional boundaries that define 12 British standard regions or moves across boundaries separating 97 geographical areas. If none of (a) or (b) or (c) applies to a given job move, then the individual is classified as a within-company job mover. We are able to check the degree of accuracy of our estimated internal/external mover distinctions because, from 2002, the Office for National Statistics in its Annual Survey of Hours and Earnings (ASHE) provides company markers in respect of the individuals recorded in our NESPD data. Comparisons of actual and estimated outcomes are shown in Table 2 for 2002-2010. This reveals that our simple

\footnotetext{
${ }^{8}$ The 3-digit occupation classifications were changed in 1991 and 2002. In our subsequent job mover regressions that concern job title changers and job title retainers we drop these two years from the analysis.

${ }^{9}$ The 1-digit industrial classification was changed in 1982 and 1996. In regressions incorporating the identification of within- and between-company job moves we drop these two years from the analysis.
} 
methodology predicts correctly with well over $80 \%$ accuracy for both internal and external movers and for both genders. It turns out that our estimates are essentially unaffected if we chose 12 or 97 regions as part of the determination on the internal/external job move dichotomy. Accordingly, we show results (i.e. background statistics and regressions) only with respect to incorporating the 97 -areas rule. ${ }^{10}$

Table 1 reports the total NESPD observations for males and females and the average percentage shares of job stayers and movers for 1976-2010. Respective percentage shares of stayers, movers, internal movers, and external movers within total male and female observations correspond closely. For both genders, there are roughly equal shares of withinand between-company job movers. ${ }^{11}$ Table 1 also shows the estimated annual shares of male and female job movers sub-divided into those who changed or retained their job titles. Roughly two-thirds of movers - i.e. total, within-company and between-company job movers - changed job title. As for the wage construct used in the regressions - the change in the log of the real standard wage - the notable feature is that the average real wage changes of all categories of male and female job movers are more than twice as large as those of their respective job stayers, though with larger standard deviations.

\footnotetext{
${ }^{10}$ As a further robustness check, we estimate the regressions contained in Table 5 - in which we separate between- and within- company movers - for the period 2002-2010 using our indirect method of choosing movers and using the ASHE exact identifiers. There are no significant differences between estimated coefficients in the two sets of regressions.

${ }^{11}$ However, this overall share-equality does not generally capture year-on-year outcomes. Between 1976 and 1995, internal movers comprised 53\% of all movers and after 1995 they made up $43 \%$.
} 
Given our interest in cyclical effects, we show in Table 3 some comparative data characteristics for periods during which the national rate of unemployment is declining or constant $(\Delta U \leq 0)$ and periods when it is rising $(\Delta U>0)$. The male and female percentages of job movers are slightly higher during falling unemployment than rising. There is a higher incidence of male and female title changers' share of all job movers when unemployment is rising. Ages of job movers in up and down directions, whether or not a title change is involved, is symmetric and somewhat younger for women compared to men (early 30 s compared to mid-30s). The incidence of male manual workers involved in title changes is relatively high, comprising $45 \%$ of all title changers when unemployment is constant or falling and $51 \%$ when it is rising. The manual female percentages are much lower, at $16 \%$ and $19 \%$ respectively. Professional workers who change job titles account for $27 \%$ of all male title changers in both directions, with females at 20/21\%. We also show in Table 3 the average percentile positions in the NESPD wage distribution of our four mover categories - i.e. internal and external movers who either change or retain job titles. For most mover categories, average wages between up- and downphases of the cycle fall in the same 5-percentile bands. However, we can't rule out some degree of compositional effects in the case of internal job movers who change job title. For both genders, when unemployment is rising the average wage of movers lies in an adjacent lower band than when unemployment is constant or falling.

\section{Empirical framework}

Decomposition of total wage cyclicality 
We divide job movers into four mutually exclusive and exhaustive categories. These are $M_{1}=$ within-company movers who retain the same job title, $M_{2}=$ within-company movers who change job titles, $M_{3}=$ between-company movers who retain the same job title, $M_{4}=$ betweencompany movers who change job titles. Let $P_{M j}(j=1, . .4)$ be the respective proportions of the four categories.

We adopt the empirical approach of Solon, Whatley and Stevens (1997) and Devereux and Hart (2006). Define job stayers as those employees who remain in the same job in period $t$ compared to period $t-1$. Let $E\left(\Delta \ln W_{S}\right)$ be the expected wage growth of stayers. Let $E\left(\Delta \ln W_{M j}\right)(j$ $=1, . ., 4)$ be the expected wage growth of job movers. Then, overall expected wage growth, $\Delta \ln W$, is given by

$$
\begin{aligned}
\mathrm{E}(\Delta \ln W) & =\left[1-\left(\sum_{j=1}^{4} P_{M j}\right)\right] E\left(\Delta \ln W_{S}\right)+\sum_{j=1}^{4} P_{M j} E\left(\Delta \ln W_{M j}\right) \\
& =E\left(\Delta \ln W_{S}\right)+\sum_{j=1}^{4} P_{M j} E\left(\Delta \ln W_{M j}-\Delta \ln W_{S}\right) .
\end{aligned}
$$

We proxy the business cycle by the change in the national unemployment rate, $\Delta U$.

Then, differentiating (1) with respect to $\Delta U$ gives

(2) $\frac{\partial E(\Delta \ln W)}{\partial(\Delta U)}=\frac{\partial E\left(\Delta \ln W_{S}\right)}{\partial(\Delta U)}+\sum_{j=1}^{4} P_{M j}\left[\frac{\partial E\left(\Delta \ln W_{M j}-\Delta \ln W_{S}\right)}{\partial(\Delta U)}\right]+\sum_{j=1}^{4}\left[\frac{E\left(\Delta \ln W_{M j}-\Delta \ln W_{S}\right) \partial P_{M j}}{\partial(\Delta U)}\right]$.

Wage growth is conditioned by three influences: (i) cyclical wage responses of job stayers, (ii) incremental effects of the cyclical wages of job movers relative to job stayers, and (iii) the cyclicality of the rate of job changing. We can re-express (2) in terms of the contributory shares of (i)-(iii), thus 


$$
\text { (3) } \begin{aligned}
\frac{\partial E(\Delta \ln W)}{\partial(\Delta U)}= & {\left[1-\left(\sum_{j=1}^{4} P_{M j}\right)\right]\left[\frac{E\left(\Delta \ln W_{S}\right)}{\partial \Delta U}\right]+\sum_{j=1}^{4} P_{M j}\left[\frac{\partial E\left(\Delta \ln W_{M j}\right)}{\partial(\Delta U)}\right]+} \\
& \sum_{j=1}^{4}\left[\frac{E\left(\Delta \ln W_{M j}-\Delta \ln W_{S}\right) \partial P_{M j}}{\partial(\Delta U)}\right] .
\end{aligned}
$$

\section{Estimation}

Estimation of (2) is conducted by the well-known two-step regression approach, first introduced in Solon, Barsky, and Parker (1994), to overcome the problems associated with estimating wage effects disaggregated to the level of the individual arising from national-level changes in unemployment rates (Moulton, 1986).

For individual $i$ at time $t$, the step-one regression is expressed

(4) $\Delta \ln w_{i t}=\alpha A_{i t}+\sum_{t=1}^{T} \beta_{o t} D_{t}+\sum_{t=1}^{T} \sum_{j=1}^{4} \beta_{j t} M_{j i t} D_{t}+\epsilon_{i t}$

where $w_{i t}$ is the real standard hourly wage rate, $\mathrm{A}_{\mathrm{it}}$ represents a cubic in age ${ }^{12}, D_{t}$ denotes a binary variable equal to 1 if the observation is from year $t, M_{j i t} D_{t}$ represents interactions between the mover identifiers and the time dummies, $\varepsilon_{i t}$ is an error term.

In step-two we have

(5) $\hat{\beta}_{k t}=\gamma_{k 0}+\gamma_{k 1} \Delta U_{t}+\gamma_{k 2} Y_{e a r_{t}}+\mu_{k t} \quad(k=0, \ldots, 4)$.

${ }^{12}$ Our data set (see next Section) does not include work experience and so we use age in its place. 
where Year $_{t}$ is a time trend and $\mu_{k t}$ is an error term. Comparing with the decomposition presented in equation (2), the estimated $\gamma_{k 1}$ 's in (5) give the cyclical responses of the real wages of job stayers $\left(\gamma_{01}\right)$ and the four incremental wage effects related to job movers $\left(\nu_{11}, ..\right)$ $\gamma_{41}$ ). We estimate (4) by OLS and (5) by weighted least squares (WLS) with the weight given by the number of individuals observed in a given year.

As for the last expression in (2), relating to the rate of job moves, we again use the twostep approach. Using the mover dummies $M_{j i t}(j=1, . .4)$, we estimate the linear probability model $^{13}$

(6) $M_{j i t}=\delta A_{j i t}+\sum_{t=1}^{T} \eta_{j t} D_{t}+\mu_{j i t}$

using WLS, with the second stage given by

(7) $\widehat{\eta}_{j t}=\lambda_{j 0}+\lambda_{j 1} \Delta U_{t+} \lambda_{j 2}$ Year $_{t}+\omega_{j t}$

\section{Estimates}

We start by reporting results for job stayers and job movers without differentiating between intra- and inter-company moves. Figures $2 \mathrm{a}$ and $2 \mathrm{~b}$ show age-corrected plots of real wage changes of job stayers, job movers who change job titles, and job movers who retain job titles against the change in the national unemployment rate. These are derived from the first

\footnotetext{
${ }^{13}$ We use a linear probability model to allow us to retain the two-step approach in both wage change and job change equations. We have verified that - within a single equation specification containing robust standard errors and allowing observations within any year to be correlated - probit estimates yield very similar marginal effects.
} 
stage estimates of the regression shown in equation (4). ${ }^{14}$ Real wage movements of all three groups of males and females are strongly procyclical. Job movers who change job titles and those retaining job titles display very similar movements and these appear to be more pronounced in several sub-periods compared to job stayers. The two mover groups exhibit stronger procyclical reactions to the recession of the late 1980 s as well as to the marked and prolonged recovery that started towards the mid-1990s. Table 4 reports the second stage estimated semi-elasticities of hourly real wage changes and rate of job changes in relation to unemployment changes. These are obtained, respectively, from equations (5) and (7). A one point decrease in the rate of unemployment is associated with a $1.2 \%$ real wage increase for male stayers and a $1.1 \%$ increase for female stayers. Real wage procyclicality of both types of job movers exhibit positive and significant incremental real wage effects compared to job stayers. However, the added incremental wage effects for title changers are roughly double those of title retainers. Based on equation (3) we can decompose the contribution of these estimates to overall wage growth. Given that job stayers constitute about $90 \%$ of the total NESPD observations (see Table 1), their contribution unsurprisingly dominates. Over $13 \%$ of the total male and female contribution derives from the real wage cyclicality of job movers with title changers comprising a greater share for males (7.7\% compared to $5.4 \%)$ and title retainers a slightly greater share for females (7.5\% compared to $6.7 \%)$. Effects of the rate of job changing on expected total wage growth are derived via equations by (6) and (7). From the last two rows

\footnotetext{
${ }^{14}$ The two breaks in the mover graphs are due changes in occupational classifications - see footnote 8 .
} 
in Table 4, we find that these make small but significant procyclical contributions to overall wage cyclicality. Job changes that also involve job title changes have the greater impact.

In order to test for possible cyclical wage effects of job assignments under the RRH hypothesis, we need additionally to distinguish between intra- and inter-company job moves. Initially, we examine the internal/external mover dichotomy without distinguishing between moves involving or not involving job title changes. Figures $3 a$ and $3 b$ show the real wage movements of male and female job stayers, intra-company job movers, and inter-company job movers. ${ }^{15}$ Real wage procyclicality is evident for all three groups. As with the mover categories in Figures $2 \mathrm{a}$ and $2 \mathrm{~b}$, the real wages of within-and between-company job movers are more strongly procyclical than those of job stayers. These graphical impressions are confirmed by the regression results in Table 5. Both intra- and inter-company job moves involve significantly greater procyclical wage effects compared to those of job stayers. For men, between-company mover real wage procyclicality is considerably stronger than the within-company equivalents. As for the influence of the rate of job changing, within-and between-company changes display roughly comparable effects.

In Table 6, we combine the title change/ title retain distinction of Table 4 with the intra/inter-company distinction of Table 5. Our intra-company job mover results provide support for real wage procyclicality of internal job title changers being significantly larger than that of job stayers. From row 3 we find significant incremental effects of title changers relative to stayers.

\footnotetext{
${ }^{15}$ The two breaks in the mover graphs are due changes in industrial classifications - see footnote 9 .
} 
For both males and females, adding the estimated incremental coefficient to the equivalent job stayer estimate produces the outcome that a one point reduction in unemployment is associated with a $1.7 \%$ increase in the real wage of internal job movers who change job titles. These outcomes are broadly in line with the findings of Solon, Whatley and Stevens (1997). ${ }^{16}$ However, we provide substantial added value because the estimates here are derived from a very large and comprehensive panel of a national workforce. In contrast, from row 2 we find that male and female internal job movers who retain job titles display real wage procyclicality that is not significantly different from job stayers.

In line with earlier studies, we also find that inter-company real wage procyclicality among job movers is significantly higher than among job stayers. The new finding provided in Table 6 is that this well-known outcome derives from both job movers who change job titles and those who retain job titles. Male inter-company title changers display a semi-elasticity of -2.4 and females -1.7. For title retainers moving between companies, the respective elasticities are -2.1 and -1.6 . In the case of title retainers, this constitutes a significant difference compared to their equivalents who change jobs within the company.

Finally, and in general, the rate of job changing contributes quite modestly to overall wage procyclicality.

\section{Concluding remarks}

Real wages in the British labor market respond strongly and flexibly to the prevailing macroeconomic climate. The past 35 years have been marked by highly pro-cyclical real wages

\footnotetext{
${ }^{16}$ More particularly, our results support the Byers' company findings of these authors given significant procyclicality of both stayers' and internal title changers' real wages.
} 
with respect to job stayers, internal job movers and external job movers. Because of their relatively large numbers, job stayers account for a substantial part of the strong national real wage procyclicality. Relative to job stayers, we find markedly higher real wage procyclicality is associated with job moves between-companies. Moreover, this is true whether or not job moves involve job re-grading. Within companies, however, a distinction between moves involving job re-grading and those in which the the same job title is retained does make a difference. Internal job movers who do not change their 3-digit occupation classifications exhibit the same degree of wage procyclicality as job stayers. Internal job movers whose occupations are re-classified experience significantly stronger real wage procyclicality than job stayers. This is consistent with the wage-related predictions of the $\mathrm{RRH}$ job re-grading hypothesis, and particularly the result obtained by Solon, Whatley and Wilson (1997) for interwar wages in the Byers Company. Thr result differs, however, from more contemporary United States studies based on longitudinal micro data where no such wage effects are established. 


\section{References}

Beaudry, Paul and John DiNardo.1991. "The effect of implicit contracts on the movement of wages over the business cycle: evidence from micro data." Journal of Political Economy 99: 665-688.

Bils, Mark J 1985. Real wages over the business cycle: evidence from panel data. Journal of Political Economy 93, 666-689.

Devereux, Paul J. 2000. Task assignment over the business cycle. Journal of Labor Economics 18 : 98-124.

Devereux, Paul J. 2002. Occupational upgrading and the business cycle. Labour 16: 423-452.

Devereux, Paul J and Robert A Hart. 2006. Real wage cyclicality of job stayers, within-company job movers, and between-company job movers. Industrial and Labor Relations Review 60: 105-119.

Devereux, Paul J and Robert A Hart. 2007. The spot market matters: evidence on implicit contracts from Britain. Scottish Journal of Political Economy 54: 661-683.

Gertler, Mark and Antonella Trigari. 2009. Unemployment fluctuations with staggered Nash bargaining. Journal of Political Economy, 117: 38-86.

Grant, Darren. 2003. "The effect of implicit contracts on the movement of wages over the business cycle: evidence for the National Longitudinal Surveys." Industrial and Labor Relations Review 56: 393-408.

Grout, Paul. 1984. Investment and wages in the absence of binding contracts: a Nash bargaining approach. Econometrica 52: 449-460.

Hagedorn, Marcus and lourii Manovskii. 2009. Spot wages over the business cycle? Mimeo. Hall, Robert E. 1974. The process of inflation in the labor market. Brookings Papers on Economic Activity: 343-393.

Harris, Milton and Bengt Holmstrom. 1982. A theory of wage dynamics. Review of Economic Studies 49: 315-333.

Kilponen, Juha and Torsten Santavirta. 2010. New evidence on implicit contracts from linked employer-employee data. Scandinavian Journal of Economics 112: 864-883. 
MacLeod, W Bentley, and James M Malcomson. 1993. Investments, Holdup, and the Form of Market Contracts. American Economic Review, 83: 811-837.

Malcomson, James M. 1999. Individual employment contracts. In Orley Ashenfelter and David Card (eds.) Handbook of Labor Economics, Chapter 35, Vol. 3B: 2291-2372.

Martins, Pedro S, Gary Solon, and Jonathan P Thomas. 2010. Measuring what employers do about entry wages over the business cycle: a new approach. Bonn: IZA Discussion Paper 4757.

McDonald James T, and Christopher Worswick. 1999. Wages, Implicit Contracts and the Business Cycle: Evidence from Canadian Micro Data. Journal of Political Economy, 107: 884-892.

Moulton, Brent R. 1986. Random group effects and the precision of regression estimates. Journal of Econometrics 32: 385-397.

Oi, Walter Y. 1962. Labor as a quasi-fixed factor. Journal of Political Economy 70: 538-555.

Pissarides, Christopher A. 2009. The unemployment volatility puzzle: is wage stickiness the answer? Econometrica 77, 1339-1369.

Reder, Melvin W. 1955. The theory of occupational wage differentials. American Economic Review 45: 833-852.

Reynolds, Lloyd G. 1951. The structure of labor markets. New York: Harper and Brothers.

Shin, Donggyn and Kwanho Shin. 2008. Why are the wages of job stayers procyclical? Macroeconomic Dynamics 12: 1-21

Solon, Gary, Robert Barsky, and Jonathan A. Parker. 1994. Measuring the cyclicality of real wages: how important is composition bias? Quarterly Journal of Economics 109, 1-26.

Solon, Gary, Warren Whatley, and Ann Huff Stevens. 1997. Wage changes and intrafirm job mobility over the business cycle: two case studies. Industrial and Labor Relations Review 50: $402-415$.

Thomas, Jonathan P and Tim Worrall. 1988. Self-enforcing wage contracts. Review of Economic Studies 55: 541-553.

Thomas, Jonathan P and Tim Worrall. 2007. Limited commitment models of the labour market. Scottish Journal of Political Economy: 750-773.

Thurow, Lester C. 1975. Generating inequality. New York: Basic Books. 
Wilson, Beth Anne. 1997. Movements of wages over the business cycle; and intra-firm view. Working paper. Washington, DC: Federal Reserve Board. 
Table 1 Descriptive statistics, NESPD 1976-2010

\begin{tabular}{|l|c|c|}
\hline & Men & Women \\
\hline Total observations & $1,791,605$ & 905,994 \\
\hline Job stayers \% share of total observations & 91.6 & 90.5 \\
\hline Job movers \% share of total observations & 8.4 & 9.5 \\
\hline Internal movers \% share of total observations & 4.2 & 4.4 \\
\hline External movers \% share of total observations & 4.2 & 61.9 \\
\hline Title changers \% of all job movers & 67.1 & 67.8 \\
\hline Title changers \% share of internal moves & 63.2 & $37.7(37)$ \\
\hline Title changers \% share of external moves & 71.0 & $0.033(0.120)$ \\
\hline Average age (median age) & $40.4(40)$ & $0.080(0.170)$ \\
\hline$\Delta \ln W:$ stayers (standard deviation) & $0.025(0.139)$ & $0.075(0.158)$ \\
\hline$\Delta \ln W:$ internal title changers (standard deviation) & $0.061(0.196)$ & $0.079(0.193)$ \\
\hline$\Delta \ln W:$ internal title retainers (standard deviation) & $0.063(0.189)$ & \\
\hline$\Delta \ln W:$ external title changers (standard deviation) & $0.074(0.271)$ & \\
\hline$\Delta \ln W:$ external title retainers(standard deviation) & $0.072(0.223)$ & \\
\hline
\end{tabular}


Table 2 Intra-company and inter-company job moves: estimated and actual, 2002-2010

\begin{tabular}{|l|c|c|c|c|}
\hline & \multicolumn{2}{|l|}{$\begin{array}{l}\text { Correctly estimated internal } \\
\text { movers/total actual internal } \\
\text { movers (\% correct) }\end{array}$} & $\begin{array}{l}\text { Correctly estimated external } \\
\text { movers/total actual external } \\
\text { movers (\% correct) }\end{array}$ \\
\hline & Men & Women & Men & Women \\
\hline $\begin{array}{l}\mathbf{1 2} \text { regions, 1-digit industry, } \\
\text { public/private sector }\end{array}$ & $\begin{array}{c}5897 / 6881 \\
(85.7)\end{array}$ & $\begin{array}{c}4339 / 4916 \\
(88.3)\end{array}$ & $\begin{array}{c}15648 / 18100 \\
(86.5)\end{array}$ & $\begin{array}{c}10049 / 11920 \\
(84.3)\end{array}$ \\
\hline $\begin{array}{l}\text { 97 regions, 1-digit industry, } \\
\text { public/private sector }\end{array}$ & $\begin{array}{c}5547 / 6881 \\
(80.6)\end{array}$ & $\begin{array}{c}4151 / 4916 \\
(84.4)\end{array}$ & $\begin{array}{c}16218 / 18100 \\
(89.6)\end{array}$ & $\begin{array}{c}10391 / 11920 \\
(87.2)\end{array}$ \\
\hline
\end{tabular}


Table 3 Job movers and unemployment changes: 1976 - 2010

\begin{tabular}{|c|c|c|c|c|}
\hline \multirow[b]{2}{*}{ Unemployment change } & \multicolumn{2}{|c|}{ Men } & \multicolumn{2}{|c|}{ Women } \\
\hline & $\mathbf{\Delta U} \leq \mathbf{0}$ & $\Delta \mathrm{U}>\mathbf{0}$ & $\Delta \mathbf{U} \leq \mathbf{0}$ & $\Delta \mathrm{U}>0$ \\
\hline $\begin{array}{l}\text { All job movers as a percentage of all } \\
\text { individuals }\end{array}$ & 8.8 & 8.1 & 10.0 & 8.9 \\
\hline $\begin{array}{l}\text { Movers who change job title as a percentage } \\
\text { of all movers }\end{array}$ & 64.5 & 70.3 & 61.0 & 63.1 \\
\hline Average age of movers who change job title & 34.9 & 35.5 & 31.6 & 31.6 \\
\hline $\begin{array}{l}\text { Average age of movers who retain their job } \\
\text { title }\end{array}$ & 36.1 & 35.4 & 32.7 & 31.7 \\
\hline $\begin{array}{l}\text { Manual workers who change job title as a } \\
\text { percentage of all job title changers }\end{array}$ & 44.6 & 51.2 & 15.5 & 18.9 \\
\hline \multirow[t]{2}{*}{$\begin{array}{l}\text { Professional workers who change job title as } \\
\text { a percentage of all job title changers }\end{array}$} & 26.9 & 26.8 & 21.3 & 20.3 \\
\hline & \multicolumn{4}{|c|}{ Percentile range in total wage distribution } \\
\hline Internal movers, same job title & $60-65$ & $60-65$ & $60-65$ & $60-65$ \\
\hline Internal movers, changed job title & $55-60$ & $50-55$ & $50-55$ & $45-50$ \\
\hline External movers, same job title & $65-70$ & $65-70$ & $65-70$ & $60-65$ \\
\hline External movers, changed job title & $50-55$ & $50-55$ & $50-55$ & $50-55$ \\
\hline
\end{tabular}


Table 4 Job stayers and job movers with retained or changed titles: 1976-2010

\begin{tabular}{|c|c|c|c|c|}
\hline & \multicolumn{2}{|c|}{ MEN } & \multicolumn{2}{|c|}{ WOMEN } \\
\hline & Coefficient on $\Delta U_{t}$ & $\begin{array}{c}\% \text { of total wage } \\
\text { cyclicality }\end{array}$ & Coefficient on $\Delta \mathrm{U}_{\mathrm{t}}$ & $\begin{array}{c}\% \text { of to total wage } \\
\text { cyclicality }\end{array}$ \\
\hline & \multicolumn{4}{|c|}{ REAL WAGE CHANGES } \\
\hline Job stayers & $\begin{array}{c}-1.230 \\
(0.284)^{* *}\end{array}$ & 83.4 & $\begin{array}{c}-1.057 \\
(0.306)^{* *}\end{array}$ & 80.3 \\
\hline $\begin{array}{l}\text { Job movers: retained job titles } \\
\text { (incremental effects) }\end{array}$ & $\begin{array}{c}-0.315 \\
(0.128)^{*}\end{array}$ & 5.4 & $\begin{array}{c}-0.372 \\
(0.124)^{* *}\end{array}$ & 7.5 \\
\hline \multirow[t]{2}{*}{$\begin{array}{l}\text { Job movers: changed job titles } \\
\text { (incremental effects) }\end{array}$} & $\begin{array}{c}-0.842 \\
(0.140)^{* *}\end{array}$ & 7.7 & $\begin{array}{c}-0.654 \\
(0.136)^{* *}\end{array}$ & 6.7 \\
\hline & \multicolumn{4}{|c|}{ RATE OF JOB CHANGING } \\
\hline Retained job titles & $\begin{array}{c}-0.003 \\
(0.001)^{* *}\end{array}$ & 1.4 & $\begin{array}{c}-0.004 \\
(0.002)^{*}\end{array}$ & 2.4 \\
\hline Changed job titles & $\begin{array}{c}-0.006 \\
(0.002)^{* *}\end{array}$ & 2.1 & $\begin{array}{c}-0.008 \\
(0.002)^{* *}\end{array}$ & 3.1 \\
\hline Step 1 observations & $1,802,517$ & & 912,129 & \\
\hline Step 2 observations (same job, job moves) & 35,33 & & 35,33 & \\
\hline
\end{tabular}

Notes: Robust standard errors in parenthesis. Results refer to step 2 of 2-step estimation. ${ }^{* *}$ statistically significant at the .01 level,

* statistically significant at the .05 level, two-tail test. Job mover regressions have two fewer observations in step 2 because of

changes in occupational classifications (see Footnote 8). 
Table 5 Job stayers and job movers within and between companies: 1976-2010

\begin{tabular}{|c|c|c|c|c|}
\hline & \multicolumn{2}{|c|}{ MEN } & \multicolumn{2}{|c|}{ WOMEN } \\
\hline & Coefficient on $\Delta \mathrm{U}_{\mathrm{t}}$ & $\begin{array}{c}\text { \% of total wage } \\
\text { cyclicality }\end{array}$ & Coefficient on $\Delta \mathrm{U}_{\mathrm{t}}$ & $\begin{array}{c}\% \text { of to total wage } \\
\text { cyclicality }\end{array}$ \\
\hline & \multicolumn{4}{|c|}{ REAL WAGE CHANGES } \\
\hline Job stayers & $\begin{array}{c}-1.228 \\
(0.284)^{* *}\end{array}$ & 84.5 & $\begin{array}{c}-1.055 \\
(0.306)^{* *}\end{array}$ & 81.4 \\
\hline $\begin{array}{l}\text { Job movers: same company } \\
\text { (incremental effects) }\end{array}$ & $\begin{array}{c}-0.350 \\
(0.112)^{* *}\end{array}$ & 3.5 & $\begin{array}{c}-0.533 \\
(0.125)^{* *}\end{array}$ & 4.7 \\
\hline \multirow[t]{2}{*}{$\begin{array}{l}\text { Job movers: new company } \\
\text { (incremental effects) }\end{array}$} & $\begin{array}{c}-1.103 \\
(0.140)^{* *}\end{array}$ & 9.4 & $\begin{array}{c}-0.632 \\
(0.154)^{* *}\end{array}$ & 9.2 \\
\hline & \multicolumn{4}{|c|}{ RATE OF JOB CHANGING } \\
\hline Same company & $\begin{array}{c}-0.005 \\
(0.003)\end{array}$ & 0.9 & $\begin{array}{c}-0.006 \\
(0.004)\end{array}$ & 1.43 \\
\hline New company & $\begin{array}{c}-0.006 \\
(0.003)^{*}\end{array}$ & 1.8 & $\begin{array}{c}-0.007 \\
(0.003)^{* *}\end{array}$ & 3.3 \\
\hline Step 1 observations & $1,803,570$ & & 912,997 & \\
\hline Step 2 observations (same job, job moves) & 35,33 & & 35,33 & \\
\hline
\end{tabular}

Notes: Robust standard errors in parenthesis. Results refer to step 2 of 2-step estimation. ${ }^{* *}$ statistically significant at the .01 level,

* statistically significant at the .05 level, two-tail test. Job mover regressions have two fewer observations in step 2 because of changes in industrial classifications classification (see Footnote 9). 
Table 6 Job stayers, job movers with retained and changed job titles, and moves within and between companies: 1976-2010

\begin{tabular}{|c|c|c|c|c|}
\hline & \multicolumn{2}{|c|}{ MEN } & \multicolumn{2}{|c|}{ WOMEN } \\
\hline & $\begin{array}{c}\text { Coefficient on } \\
\Delta U_{t}\end{array}$ & $\begin{array}{l}\text { \% of wage } \\
\text { cyclicality }\end{array}$ & $\begin{array}{c}\text { Coefficient on } \\
\Delta \mathrm{U}_{t}\end{array}$ & $\begin{array}{l}\text { \% of wage } \\
\text { cyclicality }\end{array}$ \\
\hline & \multicolumn{4}{|c|}{ REAL WAGE CHANGES } \\
\hline Stayers & $\begin{array}{c}-1.229 \\
(0.284)^{* *}\end{array}$ & 84.0 & $\begin{array}{c}-1.054 \\
(0.306)^{* *}\end{array}$ & 81.0 \\
\hline $\begin{array}{l}\text { Internal movers: retained job titles } \\
\text { (incremental effects) }\end{array}$ & $\begin{array}{l}-0.050 \\
(0.156) \\
\end{array}$ & 1.5 & $\begin{array}{l}-0.296 \\
(0.159)\end{array}$ & 2.5 \\
\hline $\begin{array}{l}\text { Internal movers: changed job titles } \\
\text { (incremental effects) }\end{array}$ & $\begin{array}{c}-0.504 \\
(0.128)^{* *}\end{array}$ & 3.5 & $\begin{array}{c}-0.669 \\
(0.130)^{* *}\end{array}$ & 4.4 \\
\hline $\begin{array}{l}\text { External movers: retained job titles } \\
\text { (incremental effects) }\end{array}$ & $\begin{array}{c}-0.911 \\
(0.140)^{* *}\end{array}$ & 1.9 & $\begin{array}{c}-0.571 \\
(0.193)^{* *} \\
\end{array}$ & 2.0 \\
\hline \multirow[t]{2}{*}{$\begin{array}{l}\text { External movers: changed job titles } \\
\text { (incremental effects) }\end{array}$} & $\begin{array}{c}-1.160 \\
(0.177)^{* *}\end{array}$ & 5.3 & $\begin{array}{c}-0.623 \\
(0.194)^{* *}\end{array}$ & 4.2 \\
\hline & \multicolumn{4}{|c|}{ RATE OF JOB CHANGING } \\
\hline Internal: retained job titles & $\begin{array}{l}-0.002 \\
(0.001)\end{array}$ & 0.7 & $\begin{array}{l}-0.003 \\
(0.002)\end{array}$ & 1.0 \\
\hline Internal: changed job titles & $\begin{array}{l}-0.003 \\
(0.002) \\
\end{array}$ & 0.9 & $\begin{array}{l}-0.004 \\
(0.003) \\
\end{array}$ & 1.7 \\
\hline External: retained job titles & $\begin{array}{c}-0.001 \\
(0.001)\end{array}$ & 0.5 & $\begin{array}{c}-0.002 \\
(0.001)^{*}\end{array}$ & 0.7 \\
\hline External: changed job titles & $\begin{array}{c}-0.005 \\
(0.002)^{*}\end{array}$ & 1.8 & $\begin{array}{c}-0.005 \\
(0.002)^{* *} \\
\end{array}$ & 2.6 \\
\hline Step 1 observations & $1,791,581$ & & 905.984 & \\
\hline Step 2 observations (same job, job moves) & 35,31 & & 35,31 & \\
\hline
\end{tabular}

Notes: Robust standard errors in parenthesis. Results refer to step 2 of 2 -step estimation. ${ }^{* *}$ statistically significant at the .01 level,

* statistically significant at the .05 level, two-tail test. Job mover regressions have four fewer observations in step 2 because of changes in the occupational and industrial classifications (see Footnotes 8 and 9). 


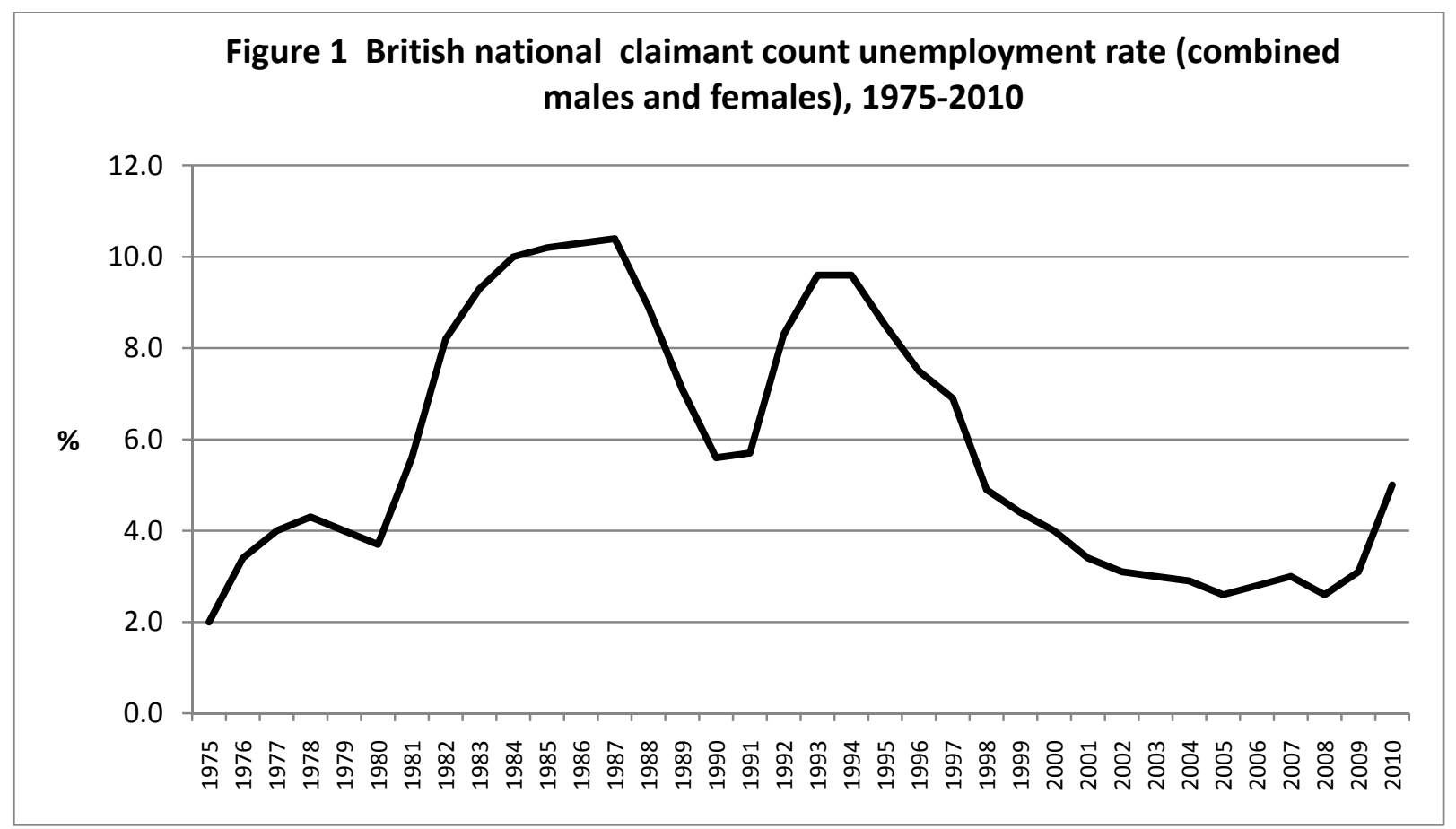

Source: Office for National Statistics 
Figure 2a Real wage changes of male job movers, job title changers, and job title retainers: $1976-2010$

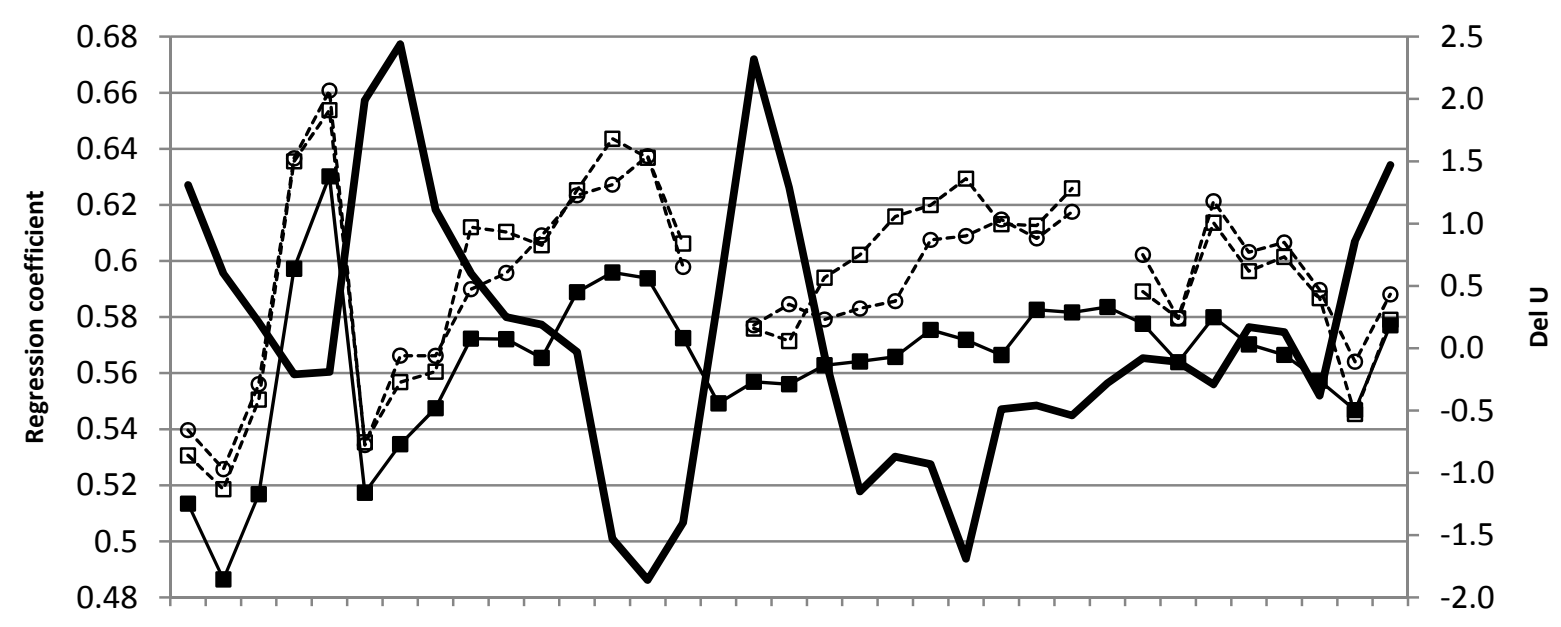

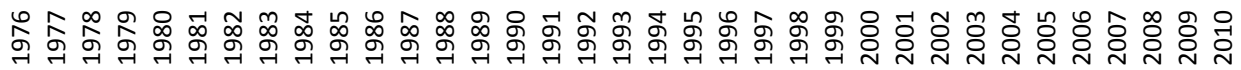

$\longrightarrow$ Stayers ---๑--- Job movers:same job title ---曰--- Job movers:job title changers $\longrightarrow$ delU

Figure $\mathbf{2 b}$ Real wage changes of female job movers, job title changers, and job title retainers: 1976-2010

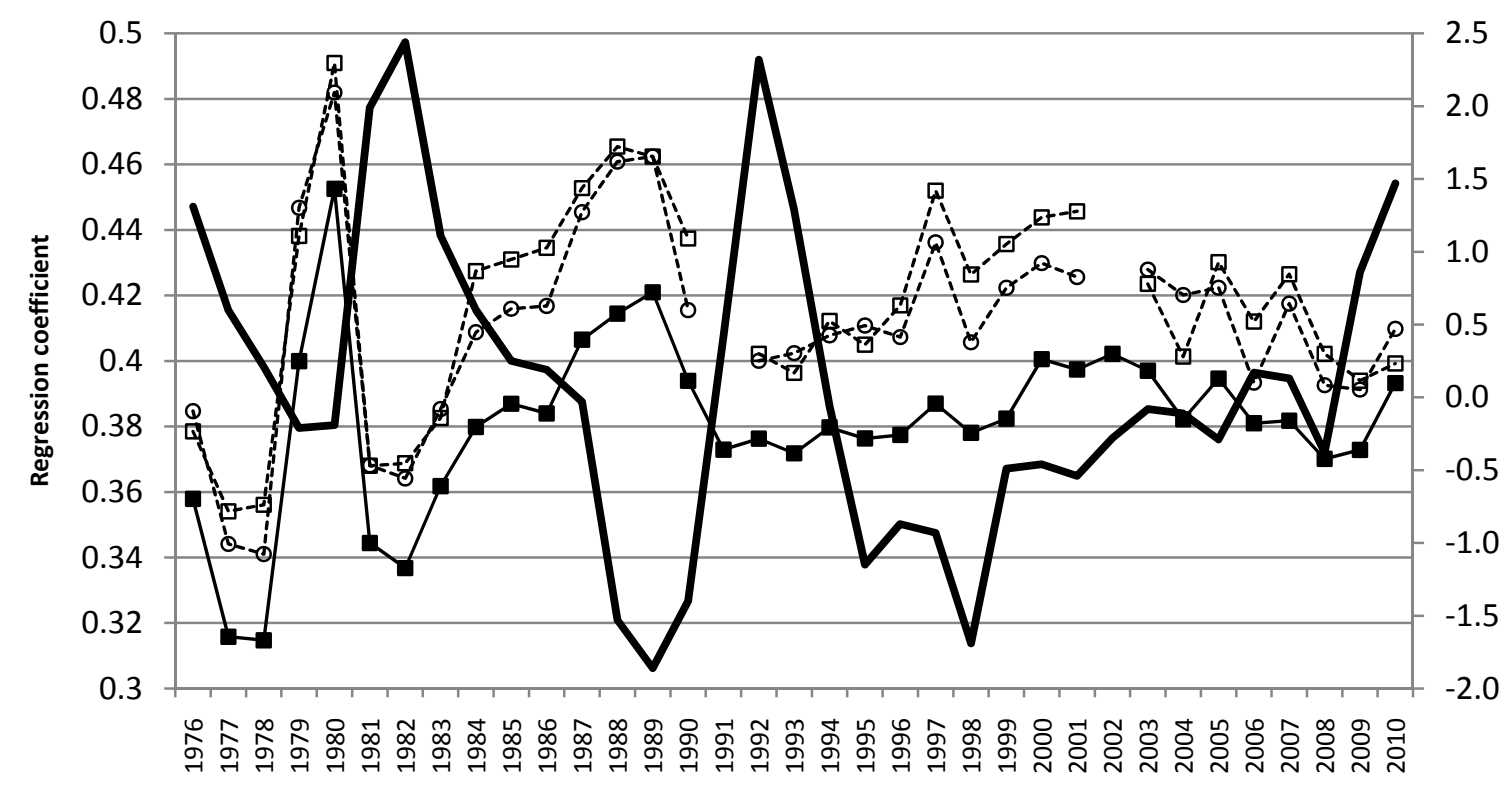

$\frac{2}{\square}$

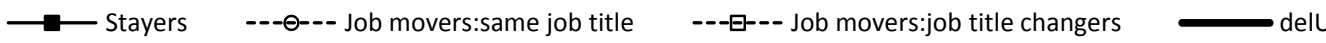



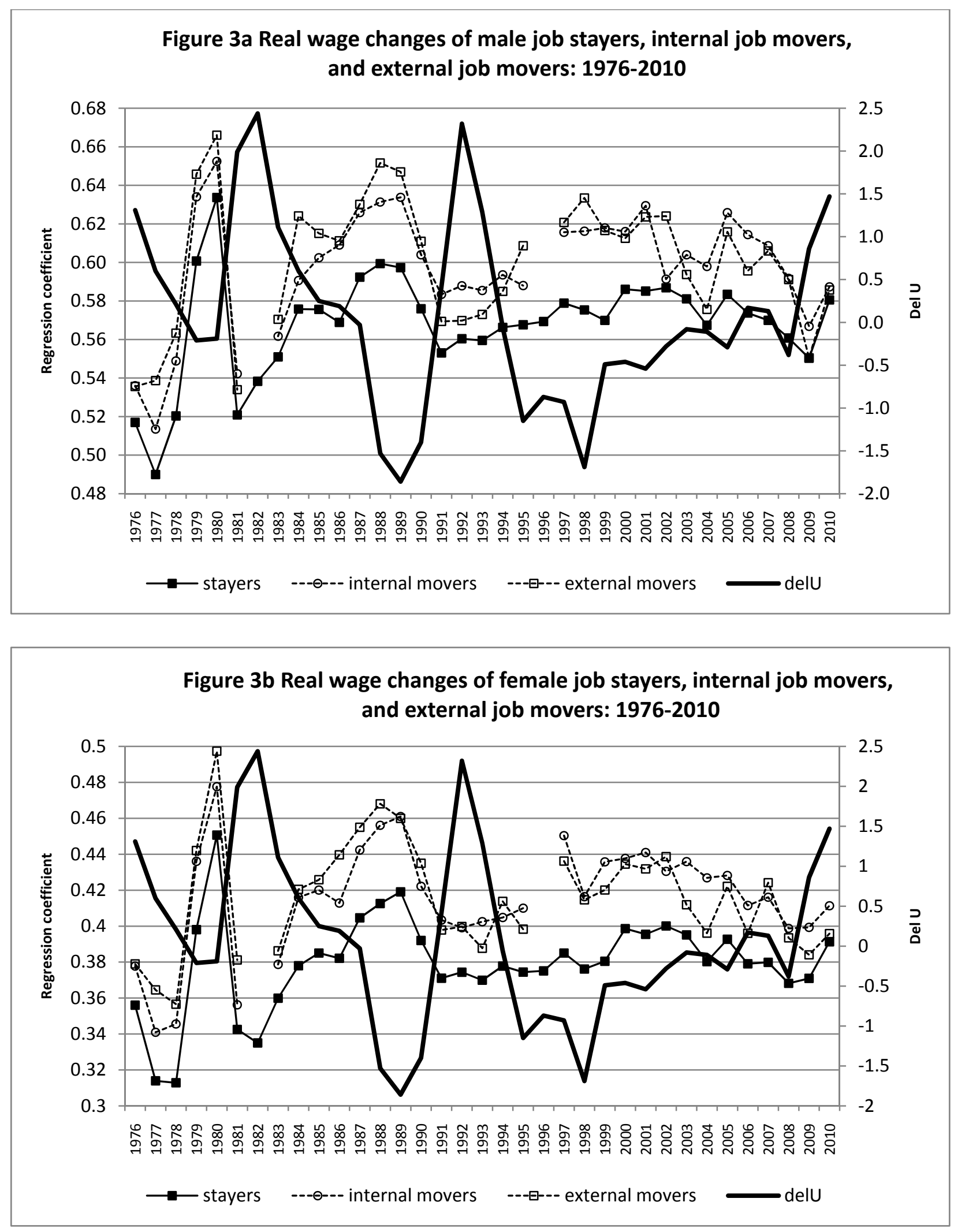